\title{
Short communication \\ Seasonal variations in scrotal circumference and semen characteristics of Naimi and Najdi rams in Saudi Arabia
}

\author{
Y. Al-Anazi ${ }^{1}$, M. G. Al-Mutary ${ }^{2 \#}$, M. Al-Ghadi ${ }^{1}$, M. M. Alfuraiji $^{3}$, A. R. Al-himaidi ${ }^{1}$ \& A. Ammari ${ }^{1}$ \\ 'Department of Zoology, College of Science, King Saud University, Riyadh, Saudi Arabia. \\ ${ }^{2}$ Basic Sciences Department, College of Education, Imam Abdulrahman Bin Faisal University, Dammam, Saudi Arabia. \\ ${ }^{3}$ Animal Production Department, College of Food Sciences and Agriculture, King Saud University, Riyadh, Saudi Arabia.
}

(Received 11 February 2017; Accepted 12 May 2017; First published online 22 May 2017)

\author{
Copyright resides with the authors in terms of the Creative Commons Attribution 4.0 South African License. \\ See: http://creativecommons.org/licenses/by/4.0/za \\ Condition of use: The user may copy, distribute, transmit and adapt the work, but must recognize the authors and the South African \\ Journal of Animal Science.
}

\begin{abstract}
In the present study, the authors analysed the effects of seasonal variations on the scrotal circumference and semen characteristics in two ram breeds in Saudi Arabia, namely Naimi and Najdi. Five rams of each breed were used in this experiment. Scrotal circumference and semen characteristics were evaluated in each ram twice a month throughout the year. Significant differences were observed in the scrotal circumference between various seasons. The largest production of semen was recorded mainly in spring, whereas the lowest semen volume was produced in summer. The $\mathrm{pH}$ of the semen was slightly alkaline and significantly lower in autumn than in spring. Furthermore, the highest value of the total number of sperm per ejaculate was observed in spring for both breeds. The results indicated that mass motility increased significantly in autumn compared with winter, spring, and summer. Progressive motility was significantly lower during the months of summer and spring. However, no significant differences were recorded between autumn and winter. Hence, the presence of significant seasonal variations in semen quantity and quality of Naimi and Najdi rams suggests the viability of increased utilization of rams in spring and autumn for semen collection and reproductive practices.
\end{abstract}

Keywords: Mass motility, progressive motility, semen volume, sperm concentration.

\#Corresponding author: mgalmutary@uod.edu.sa

A wide variety of sheep breeds exists owing to geographical isolation, cross breeding, selection, and genetic drift. Najdi and Naimi are two native sheep breeds that are found in the Kingdom of Saudi Arabia. Both are fat-tailed sheep. However, the Najdi breed is black coated, whereas the Naimi breed is white in colour with a distinguishing brown head (Ali \& Naomi, 1992; Muneeb et al., 2012). In comparison with other domestic livestock species, sheep are widely known for marked seasonality of breeding activity. The phenomenon is regulated by the annual cycle of daily photoperiod. Sheep are sexually active mainly in late summer and early autumn when the day length is shorter. Moreover, physiological and sexual variations in rams are less pronounced than in ewes. For instance, rams are sexually active throughout the year. However, ovulation in ewes is limited to certain periods (Rosa \& Bryant, 2003).

With the introduction of artificial insemination (Al) in animals, there is growing need to acquire knowledge about the variations in semen characteristics. Semen quality in terms of sperm ejaculate is affected dramatically by the environment in temporary and permanent ways, which include ambient temperature, feeding, age, period of daylight, conditions during semen collection, and management (Foote, 1978). The reproductive activity of sheep and the effect of season on the quality of semen have been studied by many researchers. A study on the effect of seasons on the reproductive ability of rams raised in United Arab Emirates (UAE) suggested that maximum sexual activity in otherwise continuously breeding rams, observed during winter, was reflected in high sperm concentration (Ibrahim, 1997). Moreover, monthly variations were detected in reproductive and semen characteristics, such as sperm concentration and motility, ejaculate volume, relative testes volume, and serum testosterone levels, which were found to be higher in autumn (Gundogan \& Demirci, 2003). The quality of semen is influenced by several parameters, including sperm concentration, abnormality, and viability (Zhang et al., 1998). A study by D'Alessandro \& Martemucci (2003) assessed the effects of seasonal variations on semen freezability, and observed that the 
highest post-thaw survival of sperm was displayed by semen frozen in summer and autumn. Seasonal variations contribute to differences in semen volume, sperm motility, scrotal circumference, and testosterone level. However, the semen of Suffolk and Lincoln rams, and of those raised in Hungary is suitable for Al throughout the year (Oláh et al., 2013; Benmoula et al., 2017).

On the other hand, a study by Al-Samarrae (2006) indicated an association between reproductive ability and fitness and the genotype of the Iraqi sheep. Abdel-Rahman et al. (2000) reported variations in semen characteristics between native ram breeds (Najdi and Naimi) and imported ones (Merino, Somalian, and Sudanese). The imported rams displayed reduced sperm concentration, but high individual sperm motility and a higher concentration of inorganic constituents. Considerable seasonal variations were observed in various breeds of Hungarian sheep and included semen characteristics such as volume, percentage motility, $\mathrm{pH}$, mass motility, thawing, and heat resistance (Oláh et al., 2013). The quality of semen, morphological examination of sperm, and the volume of sperm ejaculate are important factors in determining male fertility. Therefore, increasing interest in and the need to obtain more information about the behaviour and reproductive physiology of farm animals have developed (Garner \& Hafez, 1993; Talebi et al., 2009). Comprehensive research has not been conducted on the influence of seasonal variations on the semen characteristics of Naimi and Najdi rams. Therefore, the present study aimed to assess the influence of seasons of the year on the reproductive performance of these two ram breeds.

Ten adult rams (two years old), five of each breed (Naimi and Najdi), were used. Before semen collection began, the rams were examined to ensure that they were disease free with normal testes and sperm physiology. The rams were studied at the animal production farm, College of Food and Agriculture Sciences, King Saud University (KSU), Riyadh, Saudi Arabia, according to the principles and guidelines approved by the Research Ethics Committee of KSU.

The animals were fed concentrate pellets and hay to meet their nutritional requirements. For the qualitative and quantitative evaluation of semen characteristics, semen was collected by electro-ejaculation twice a month from each ram throughout the year. Semen collection was performed by a single person with a battery-operated ejaculator. Each stimulus consisted of 32 pulses, with each pulse lasting for two seconds. Immediately after ejaculation, fresh semen samples were transferred to the laboratory, where they were maintained at $37^{\circ} \mathrm{C}$, followed by evaluation. The semen volume was recorded immediately by measuring the collection inside a graduated glass tube, and its $\mathrm{pH}$ was determined with a $\mathrm{pH}$ meter by immersing the probe into the semen sample. Sperm concentration was determined by diluting the semen in an appropriate buffer followed by counting the sperm using a haemocytometer slide under the microscope, followed by calculation of the total number of sperm per ejaculate (volume $\times$ density) from sperm concentration. Sperm motility was calculated as a percentage of the speed of sperm flagellar movement in a given volume. The mass and progressive motility of sperm were evaluated using the computer-assisted semen analysis (CASA) platform from Hamilton Thorne (Beverly, Mass, USA) to overcome the drawbacks of manual semen analysis in measuring the kinematics of sperm motion. After the semen collection, the scrotal circumference was measured by placing a metric tape at the widest part of the scrotum.

The data were analysed with the general linear model (GLM) procedure of SAS, which was used to perform an analysis of variance (ANOVA). A $2 \times 2$ factorial experimental design was used to examine the effects of the breed (Najdi versus Naimi) and seasonal variations in the scrotal circumference, and semen characteristics (semen volume, semen $\mathrm{pH}$, mass motility, progressive motility, sperm concentration, and total sperm ejaculate). The data were expressed as the mean \pm SE for all parameters. The least significant difference (LSD) was set at $P<0.05$.

In small ruminants of temperate regions, length of day is one of the most important factors that determine the onset of the breeding season. Marked variations were observed in the scrotal circumference and semen serving capacity among various breeds of rams (Suffolk, Lincoln) from October to February. Moreover, the secretion of sexual hormones such as testosterone, follicular stimulating hormone (FSH), and luteinizing hormone (LH) was found to be season dependent (Dickson \& Sanford, 2005; Benmoula et al., 2017). Semen production in rams is influenced by several factors, such as breed, age, environmental circumstances (daylight length, ambient temperature, and humidity), and management systems, resulting in variations in the semen characteristics (Folch, 1984).

In the current study, a clear effect of season was observed on various semen parameters. As shown in Figure 1, significant differences $(P<0.05)$ among rams within each breed were found for scrotal circumference between seasons. The lowest mean value of scrotal circumference was reported in autumn, whereas the highest mean value was observed in summer. These results are consistent with those of Oláh et al. (2013), who conducted a study on seven breeds of sheep, including lle de France ram and Barbados Blackbelly ram. Other studies reported a higher scrotal circumference in autumn for bucks (breed of goats) (Al-Ghalban et al., 2004; Kridli et al., 2007) and Karakul rams (Kafi et al., 2004). Kafi et al. reported that the rams produced superior quality semen throughout late summer and autumn, and therefore could be utilized 
for Al. Scrotal circumference has been found to be directly proportional to the bodyweight and age of the animal, so mature Awassi rams are heavier and have a greater scrotal circumference than their younger counterparts (Salhab et al., 2003; Tabbaa et al., 2006).

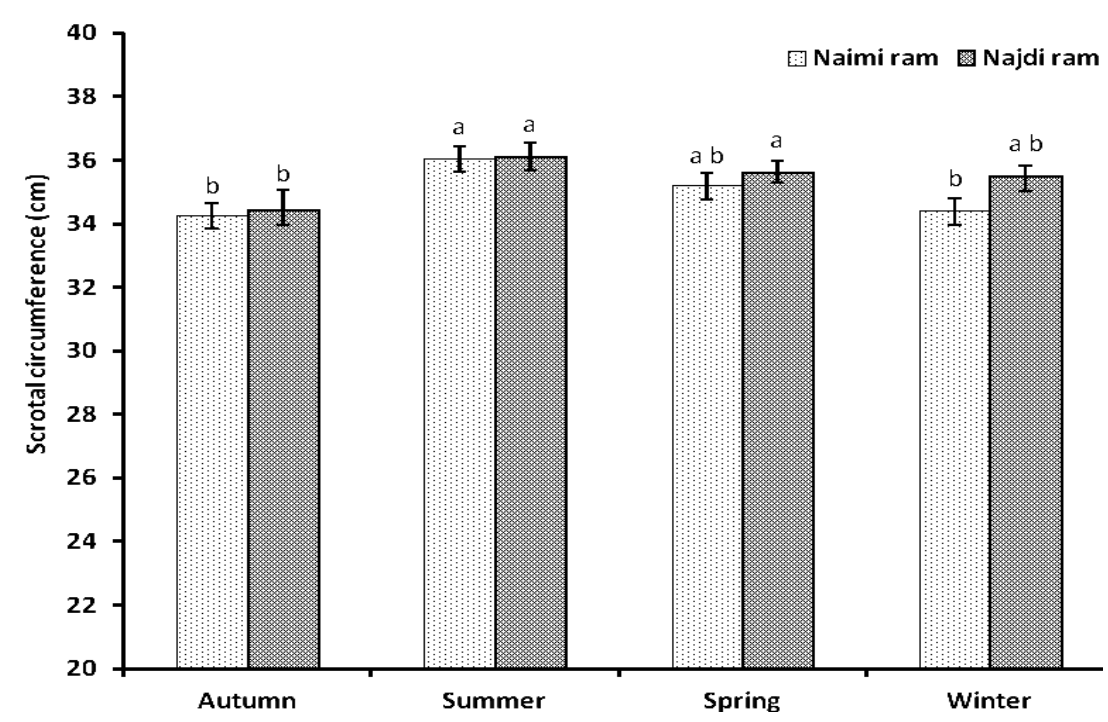

Figure 1 Seasonal variations in scrotal circumference of Naimi and Najdi rams in the four seasons (mean \pm $\mathrm{SE})$

Different letters $(\mathrm{a}, \mathrm{b})$ within a breed and between seasons are significantly different $(P<0.05)$

Seasonal variations in semen characteristics of Naimi and Najdi rams are presented in Table 1. Several authors (Menchaca et al., 2005; Safdarian et al., 2006) have observed an average volume range of 0.5 to $2 \mathrm{~mL}$ of ram semen. A higher mean semen volume was recorded among Persian Karakul rams in the autumn, which correlated with the maximum sexual activity of the animals. In this study, most of the values of semen characteristics in Najdi and Naimi rams in Riyadh region were higher than those reported by lbrahim (1997) for Chios crosses in the UAE. Semen volume, as shown in Table 1, was found to be influenced by the season of the year, achieving a lower mean value $(P<0.05)$ in summer in both Najdi and Naimi rams compared with spring, autumn, and winter. It remained significantly high $(P<0.05)$ in spring. This is contrary to the study on Chios and Friesian rams in Greece, in which it was observed that semen volume improved in autumn and summer, and decreased in spring (Karagiannidis et al., 2000).

The $\mathrm{pH}$ of semen affects the viability, motility, and capacitation of sperm (Hafez \& Hafez, 2000), which is similar to the result obtained in the present study. The delay in processing fresh undiluted semen could induce semen $\mathrm{pH}$ to become more acidic owing to the degradation of fructose by the sperm cells (Hafez \& Hafez, 2000; Zamiri et al., 2010). The best quality and quantity of semen in Naimi and Najdi rams were observed in spring and autumn, unlike previous studies that showed that semen characteristics were generally better in summer and autumn and lowest in spring (Colas et al., 1986; Mandiki et al., 1998; Karagiannidis et al., 2000). However, in a similar study with Chios rams crossbred and raised in the United Arab Emirates. Ibrahim (1997) observed an improvement in sperm motility, semen $\mathrm{pH}$, semen volume and sperm concentration mainly in winter.

Many factors affect semen quality, such as genetic mutation and environmental changes (AbdelRahman et al., 2000; GÜNdoĞAn et al., 2004), feed and nutritional factors (Colas, 1981; Toe et al., 1994), and seasonal variations (Ibrahim, 1997). Semen quality is also determined by sperm viability, which in turn affects the process of sperm capacitation. Capacitation involves several functional changes in the sperm such as changes in the plasma membrane and appearance or disappearance of certain molecules, culminating in the penetration of zona pellucida by sperm (Garner \& Hafez, 1993). The progressive motility of sperm is significant in determining the fertility potential of sperms. The sperm motility in both Najdi and Naimi rams was lower $(P<0.05)$ in summer. These results are consistent with those of Mandiki et al. (1998) and Karagiannidis et al. (2000), but were contrary to those of Talebi et al. (2009). Low sperm motility in summer is a clear indication of heat stress and high temperatures. Moreover, research conducted by many groups 
suggests that high temperatures reduce testicular activity and semen quality (Phillips \& McKenzie, 1934). In addition, the highest $(P<0.05)$ sperm concentration was recorded in spring and autumn in Naimi and Najdi rams, whereas lower concentrations were recorded in winter and summer. This trend is comparable with the results of Karagiannidis et al. (2000) in Chios and Friesian rams in Greece and Talebi et al. (2009) in Markhoz bucks of Iran. The high sperm concentration and total sperm per ejaculate correlates with high semen volume, indicating an elevated activity of glands and therefore of sexual hormones such as testosterone. Furthermore, scrotal circumference, semen volume, sperm concentration and serum testosterone level are influenced positively by the nutritional state of the animals. Proper health management with a nutritional diet assists in the development of a normal reproductive system. The results of the current study demonstrated no differences between the semen characteristics of Naimi and Najdi rams, which may be attributed to the similarity of nutritional and environmental factors.

Table 1 Seasonal variations in semen characteristics (Volume, $\mathrm{pH}$, Concentration of sperm $\left(10^{6} / \mathrm{mL}\right)$, Total sperm/ejaculate $10^{6}$ and Mass and progressive motility of sperm) of Naimi and Najdi rams (mean \pm SE)

\begin{tabular}{|c|c|c|c|}
\hline \multirow{2}{*}{ Parameters } & \multirow{2}{*}{ Season } & \multicolumn{2}{|c|}{ Breed } \\
\hline & & Naimi ram & Najdi ram \\
\hline \multirow[t]{4}{*}{ Volume (mL) } & Winter & $1.88^{\mathrm{a}} \pm 0.08$ & $1.93^{\mathrm{ab}} \pm 0.07$ \\
\hline & Spring & $2.09^{\mathrm{a}} \pm 0.05$ & $2.13^{\mathrm{a}} \pm 0.13$ \\
\hline & Summer & $1.62^{\mathrm{b}} \pm 0.06$ & $1.54^{\mathrm{C}} \pm 0.04$ \\
\hline & Autumn & $1.96^{\mathrm{a}} \pm 0.08$ & $1.85^{\mathrm{b}} \pm 0.08$ \\
\hline \multirow[t]{4}{*}{$\mathrm{pH}$} & Winter & $5.98^{\mathrm{ab}} \pm 0.04$ & $5.92^{b} \pm 0.05$ \\
\hline & Spring & $6.14^{\mathrm{a}} \pm 0.05$ & $6.17^{\mathrm{a}} \pm 0.10$ \\
\hline & Summer & $5.93^{b} \pm 0.07$ & $6.00^{\mathrm{ab}} \pm 0.08$ \\
\hline & Autumn & $5.74^{\mathrm{c}} \pm 0.09$ & $5.87^{\mathrm{b}} \pm 0.07$ \\
\hline \multirow[t]{4}{*}{ Concentration $\left(10^{6} / \mathrm{mL}\right)$} & Winter & $2861^{d} \pm 128$ & $3307^{b} \pm 120$ \\
\hline & Spring & $4367^{\mathrm{a}} \pm 73$ & $4437^{\mathrm{a}} \pm 201$ \\
\hline & Summer & $3480^{C} \pm 63$ & $3463^{b} \pm 100$ \\
\hline & Autumn & $3873^{b} \pm 115$ & $3487^{b} \pm 92$ \\
\hline \multirow[t]{4}{*}{ Total sperm/ejaculate $10^{6}$} & Winter & $5431^{\mathrm{C}} \pm 389$ & $6380^{\mathrm{b}} \pm 299$ \\
\hline & Spring & $9128^{a} \pm 305$ & $9312^{\mathrm{a}} \pm 423$ \\
\hline & Summer & $5640^{c} \pm 244$ & $5319^{c} \pm 208$ \\
\hline & Autumn & $7576^{b} \pm 331$ & $6501^{b} \pm 375$ \\
\hline \multirow[t]{4}{*}{ Mass motility (\%) } & Winter & $86.06^{\mathrm{b}} \pm 0.96$ & $85.44^{\mathrm{b}} \pm 0.93$ \\
\hline & Spring & $85.67^{b} \pm 0.64$ & $83.67^{b} \pm 0.73$ \\
\hline & Summer & $84.50^{b} \pm 0.89$ & $85.29^{b} \pm 0.83$ \\
\hline & Autumn & $91.33^{\mathrm{a}} \pm 0.91$ & $92.22^{\mathrm{a}} \pm 0.92$ \\
\hline \multirow[t]{4}{*}{ Progressive motility (\%) } & Winter & $62.67^{\mathrm{a}} \pm 1.87$ & $60.61^{a} \pm 0.87$ \\
\hline & Spring & $50.50^{\mathrm{b}} \pm 1.13$ & $47.75^{b} \pm 1.21$ \\
\hline & Summer & $45.50^{\mathrm{b}} \pm 1.64$ & $46.63^{\mathrm{b}} \pm 1.41$ \\
\hline & Autumn & $62.83^{\mathrm{a}} \pm 1.80$ & $62.94^{\mathrm{a}} \pm 1.97$ \\
\hline
\end{tabular}

${ }_{a, b, c, d}$ Means within the same column of each parameter with different superscripts differ significantly $(P<0.05)$

In conclusion, the semen characteristics of Naimi and Najdi rams displayed significant seasonal variations throughout the year. However, spring and autumn are considered the most effective seasons for the production of high-quality semen. Semen $\mathrm{pH}$, volume, concentration, and total sperm per ejaculate were significantly high in summer, whereas good sperm motility was recorded in the autumn. 


\section{Acknowledgements}

This project was supported by King Saud University, Deanship of Scientific Research, College of Sciences Research Centre, Riyadh, Saudi Arabia.

\section{Authors' Contributions}

YA conducted the research as part of his PhD in the Animal Production Department. MMA and ARA designed and supervised the whole study. AA performed animal management. MA and MGA participated in the project. YA, MA and MGA wrote the paper. All authors read and approved the final manuscript.

\section{Conflict of Interest Declaration}

The authors declare that there is no conflict of interests.

\section{References}

Abdel-Rahman, H.A., El-Belely, M.S., Al-Qarawi, A.A. \& El-Mougy, S.A., 2000. The relationship between semen quality and mineral composition of semen in various ram breeds. Small Rumin. Res. 38, 45-49.

Al-Ghalban, A.M., Tabbaa, M.J. \& Kridli, R.T., 2004. Factors affecting semen characteristics and scrotal circumference in Damascus bucks. Small Rumin. Res. 53, 141-149.

Al-Samarrae, S.H., 2006. Potentiality employment of some hematological and biochemical criterions for evaluation of productivity performance traits of Iraqi sheep. Ph.D. Thesis, University of Baghdad, Iraq.

Ali, K.E. \& Al-Naomi, A.A., 1992. Copper status of Najdi sheep in Eastern Saudi Arabia under penned and grazing conditions. Trop. Anim. Health Prod. 24, 115-120.

Benmoula, A., Badi, A., El Fadili, M., El Khalil, K., Allai, L., El Hilali., A. \& El Amiri, B., 2017. Effect of season on scrotal circumference, semen characteristics, seminal plasma composition and spermatozoa motility during liquid storage in INRA180 rams. Anim. Reprod. Sci. 180, 17-22.

Colas, G., 1981. Seasonal variations of sperm quality in adult lle-de-France rams. II. Fertilizing ability and its relation to qualitative criteria in vitro. Reprod. Nutr. Dev. 21, 399-407.

Colas, G., Guerin, Y., Lemaire, Y., Montassier, Y. \& Despierres, J., 1986. Seasonal variation in the testis diameter and sperm morphology in the Vendean ram and Texel ram. Reprod. Nutr. Dev. 26, 863-875.

D'Alessandro, A.G. \& Martemucci, G., 2003. Evaluation of seasonal variations of semen freezability in Leccese ram. Anim. Reprod. Sci. 79, 93-102.

Dickson, K.A. \& Sanford, L.M., 2005. Breed diversity in FSH, LH and testosterone regulation of testicular function and in libido of young adult rams on the southeastern Canadian prairies. Small Rumin. Res. 56, 189-203.

Folch, J., 1984. The influence of age, photoperiodism and temperature on semen production of rams. In: M.E. Courot (ed.). The male in farm animal reproduction. Springer, Amsterdam. pp. 141-160.

Foote, R.H., 1978. Factors influencing the quantity and quality of semen harvested from bulls, rams, boars and stallions. J. Anim. Sci. 47 (Suppl 2), 1-11.

Garner, D. L. \& Hafez, E. S. E., 1993. Spermatozoa and seminal plasma. In: E.S.E. Hafez (ed.). Reproduction in farm animals. Lea \& Febiger, Philadelphia. pp. 165-187.

Gundogan, M. \& Demirci, E., 2003. Monthly changes in some reproductive parameters and in testosterone and thyroxine values of rams throughout one year under continental climate conditions. Dtsch. Tierarztl. Wochenschr. 110, 450453.

Gündoğan, M., Yeni, D., Uçar, M. \& Özenç, E., 2004. Relationship between some reproductive parameters and biochemical properties of blood serum in rams. Arch. Androl. 50, 387-390.

Hafez, B. \& Hafez, E.S.E., 2000. Reproduction in farm animals. Lippincott, Williams \& Wilkins, USA.

Ibrahim, S.A., 1997. Seasonal variations in semen quality of local and crossbred rams raised in the United Arab Emirates. Anim. Reprod. Sci. 49, 161-167.

Kafi, M., Safdarian, M. \& Hashemi, M., 2004. Seasonal variation in semen characteristics, scrotal circumference and libido of Persian Karakul rams. Small Rumin. Res. 53, 133-139.

Karagiannidis, A., Varsakeli, S., Alexopoulos, C. \& Amarantidis, I., 2000. Seasonal variation in semen characteristics of Chios and Friesian rams in Greece. Small Rumin. Res. 37, 125-130.

Kridli, R.T., Tabbaa, M.J. \& Barakeh, F.S., 2007. Seasonal variation in scrotal circumference and semen characteristics of Black Bedouin and Black Bedouin-Damascus crossbred bucks. Asian-Australas J. Anim. Sci. 20, 359-364.

Mandiki, S.N.M., Derycke, G., Bister, J.L. \& Paquay, R., 1998. Influence of season and age on sexual maturation parameters of Texel, Suffolk and lle-de-France rams: 1 . Testicular size, semen quality and reproductive capacity. Small Rumin. Res. 28, 67-79.

Menchaca, A., Pinczak, A. \& Queirolo, D., 2005. Storage of ram semen at $5{ }^{\circ} \mathrm{C}$ : effects of preservation period and timed artificial insemination on pregnancy rate in ewes. Anim. Reprod. 2, 195-198.

Muneeb M., Riyadh S., Aljumaah \& Al-Shaikh M.A., 2012. Genetic diversity of Najdi sheep based on microsatellite analysis. African J. Biotechnol. 11(83), 14868-14876.

Oláh, J., Kusza, S., Harangi, S., Posta, J., Kovács, A., Pécsi, A., Budai, C. \& Jávor, A., 2013. Seasonal changes in scrotal circumference, the quantity and quality of ram semen in Hungary. Archiv Tierzucht. 56, 102-108.

Phillips, R.W. \& McKenzie, F.F., 1934. The thermoregulatory function and mechanism of the scrotum. Res. Bull. Mo. agrie, exp. Stn. 217.

Rosa, H.J.D. \& Bryant, M.J., 2003. Seasonality of reproduction in sheep. Small Rumin. Res. 48, 155-171. 
Safdarian, M., Hashemi, M. \& Kafi, M., 2006. Seasonal changes in semen quality, scrotal circumference and blood testosterone level of Persian Karakul rams. Book of Abstracts of the 57th Annual Meeting of the European Association for Animal Production (EAAP), Antalya, Turkey. 203.

Salhab, S.A., Zarkawi, M., Wardeh, M.F., Al-Masri, M.R. \& Kassem, R., 2003. Characterization and evaluation of semen in growing Awassi ram lambs. Trop. Anim. Health Prod. 35, 455-463.

Tabbaa, M.J., Kridli, R.T., Amashe, M.G. \& Barakeh, F.S., 2006. Factors affecting scrotal circumference and semen characteristics of Awassi rams. Jordan J. Agric. Sci. 2, 243-250.

Talebi, J., Souri, M., Moghaddam, A., Karimi, I. \& Mirmahmoodi, M., 2009. Characteristics and seasonal variation in the semen of Markhoz bucks in western Iran. Small Rumin. Res. 85, 18-22.

Toe, F., Lahlou-Kassi, A. \& Mukasa-Mugerwa, E., 1994. Semen characteristics of lle-de-France rams of different age and physical condition. Theriogenology. 42, 321-326.

Zamiri, M.J., Khalili, B., Jafaroghli, M. \& Farshad, A., 2010. Seasonal variation in seminal parameters, testicular size, and plasma testosterone concentration in Iranian Moghani rams. Small Rumin. Res. 94, 132-136.

Zhang, B.R., Larsson, B., Lundeheim, N. \& Rodriguez-Martinez, H., 1998. Sperm characteristics and zona pellucida binding in relation to field fertility of frozen-thawed semen from dairy Al bulls. Int. J. Androl. 21, 207-216. 